\title{
Antigenic studies on flocculating brewer's yeast, Saccharomyces cerevisiae NCYC 227
}

\author{
L. NAgARAJAN and S. UMeSh-KumaR* \\ Discipline of Microbiology and Sanitation, Central Food Technological Research Institute, Mysore 570013, India
}

(Received 1 February 1990; revised 8 May 1990; accepted 22 May 1990)

\begin{abstract}
Batch cultures of a brewer's strain of Saccharomyces cerevisiae, NCYC 227, in a defined medium exhibited characteristic flocculation during the late exponential phase of growth. However, early exponential cells were nonflocculent and flocculation of such cells could not be induced even in the presence of $\mathrm{Ca}^{2+}$. A specific glycoprotein, absent from the cell walls of non-flocculating exponentially growing cells of this yeast and those of non-flocculating strains of $S$. cerevisiae, was identified on the cell wall surface of flocculating exponentially growing cells of $S$. cerevisiae NCYC 227. Flocculent cells of $S$. cerevisiae NCYC 227 dispersed with EDTA and coated with monovalent Fab portions of the antibody showed reduced flocculation. Removal of the monovalent antibody portions from the cell surfaces induced cell flocculation in the presence of $\mathrm{Ca}^{2+}$. These results suggest a role for this glycoprotein in yeast cell flocculation.
\end{abstract}

\section{Introduction}

Flocculation of yeast cells is a particular case of cell adhesion that is of considerable interest in brewing and may provide a model system of the cell aggregation process (Rose, 1984). Though early studies described wort components that induce yeast flocculation, recent investigations have established molecules of yeast cell walls as the key substances in causing flocculation. Several authors have claimed that adhesion is due to bridges between anionic groups of the cell walls. According to Lyons \& Hough $(1970,1971)$, flocculation is due to the formation of calcium bridges through phosphodiester linkages in cell mannan, whereas Harris (1959), Mill (1964), Stewart et al. (1975), Jayatissa \& Rose (1976) and Beavan et al. (1979) claimed that phosphodiesters are not involved in flocculation and that bridge formation arises principally through carboxyl groups. Based on specific inhibition of flocculation by mannose, various authors (e.g. Taylor \& Orton, 1978; Miki et al., 1982) have suggested a lectin-like interaction between mannan and protein of adjoining cells.

Despite these reports suggesting wall-wall interactions in flocculation, studies on the gross composition of cell walls of flocculent and non-flocculent yeasts have not revealed meaningful differences (Cawley \& Ballou, 1972; Stewart, 1975; Miki et al., 1981). Flocculating yeasts when inoculated into growth medium have been shown to remain dispersed and non-flocculent during the exponential phase of growth, with cells flocculating at the stationary growth phase (Amri et al., 1982). In this paper we describe preliminary results on the antigenic variation in cell walls of a flocculent yeast strain during such a transition.

\section{Methods}

Yeast strains. The flocculating strain S. cerevisiae NCYC 227, and the non-flocculating strains $S$. cerevisiae NCYC 431, NCYC 619, NCYC 620, KD6, SD 164 Labatt and CS 101 were used. Strain CS 101 was a culture maintained in this laboratory.

Growth medium. This comprised: glucose, $200 \mathrm{~g} ;\left(\mathrm{NH}_{4}\right)_{2} \mathrm{SO}_{4}, 3 \mathrm{~g}$; $\mathrm{KH}_{2} \mathrm{PO}_{4}, 3 \mathrm{~g} ; \mathrm{CaCl}_{2}, 0.25 \mathrm{~g} ; \mathrm{MgSO}_{4} .7 \mathrm{H}_{2} \mathrm{O}, 0.25 \mathrm{~g}$; yeast extract, $4 \mathrm{~g}$; distilled water, $1000 \mathrm{ml} ; \mathrm{pH} 4.5$.

Measurement of growth and flocculation. Starter cultures of $S$. cerevisiae NCYC 227 were prepared by inoculating $50 \mathrm{ml}$ medium in $250 \mathrm{ml}$ conical flasks with cells from slope cultures and incubating at $30{ }^{\circ} \mathrm{C}$ for $12 \mathrm{~h}$. A portion of the starter was then inoculated into fresh medium to obtain an initial $O_{6} D_{60}$ of $0 \cdot 1$. After different periods of growth, cells were sedimented by centrifugation at $3600 \mathrm{~g}$ for $20 \mathrm{~min}$ at $4{ }^{\circ} \mathrm{C}$ and the $\mathrm{OD}_{660}$ of cells washed with 250 mM-EDTA solution and dispersed in deionized water was determined.

Flocculation was determined by the method described by Jayatissa \& Rose (1976). Cells of different growth phases were washed with EDTA solution and dispersed in deionized water. Cell suspension $\left(2.0 \times 10^{8}\right.$ cells $\mathrm{ml}^{-1}$ ) in deionized distilled water was distributed in tubes and flocculation was initiated by the addition of $50 \mathrm{~mm}-\mathrm{CaCl}_{2}$ solution. The degree of flocculation was expressed by applying a subjective gradation (Stewart \& Goring, 1976). 
Effect of mannose on flocculation. Flocculated cells (late stationary phase of growth, from $48 \mathrm{~h}$ cultures) were dispersed with $250 \mathrm{~mm}$ EDTA and suspended in deionized water. Mannose was added at different concentrations and flocculation was determined at $660 \mathrm{~nm}$ in the presence of $50 \mathrm{mM}-\mathrm{CaCl}_{2}$

Preparation of antigens and immunization of rabbits. Whole yeast cells (late stationary phase of growth, from $48 \mathrm{~h}$ cultures) were autoclaved in $0.02 \mathrm{M}$-citrate buffer (trisodium citrate and citric acid; $\mathrm{pH} 7.0$ ) at $121{ }^{\circ} \mathrm{C}$ for $90 \mathrm{~min}$ and the supernatant separated by centrifugation at $3600 \mathrm{~g}$ for $20 \mathrm{~min}$ at $4{ }^{\circ} \mathrm{C}$. To the chilled supernatant, cold methanol ( 2 vols) was added. The precipitate was dissolved in phosphate-buffered saline (PBS; $0.1 \mathrm{M}$-sodium phosphate buffer containing $0.85 \%$ sodium chloride, $\mathrm{pH} 7.2$ ) and was used as antigen. Rabbits were immunized with $1 \mathrm{mg}$ protein per $\mathrm{kg}$ body weight for the production of antibodies. For immunization, intramuscular (with equal volume of Freund's complete adjuvant) and intraperitoneal injections were administered alternately at weekly intervals for 4 weeks. The antiserum separated from the blood 1 week after the fourth injection was subjected to ammonium sulphate precipitation for immunoglobulins. The precipitated immunoglobulins dissolved in $0.1 \mathrm{M}$-PBS were extensively dialysed against PBS before use.

Ouchterlony double diffusion. Agarose gels ( $2 \mathrm{~mm}$ thick) were made with $0.6 \%$ agarose in $0.05 \mathrm{M}$-PBS containing $0.1 \%$ sodium azide as preservative. Wells were punched using a template and cork borers. Double diffusion was carried out at $25^{\circ} \mathrm{C}$ for $96 \mathrm{~h}$. Whole yeast cells from different growth phases, washed in $250 \mathrm{~mm}$-EDTA, suspended in $0.05 \mathrm{M}-\mathrm{PBS}$ and adjusted to identical concentrations $\left(\mathrm{OD}_{660}=2.0\right)$, were used as antigens.

Cross-absorption of the antibody. To a known volume of the antibody, freeze-dried cells of $S$. cerevisiae NCYC 227 (from an $8 \mathrm{~h}$ culture) were added in excess to absorb antibodies against antigens of these cells. The sediment obtained after centrifugation at $3600 \mathrm{~g}$ for $20 \mathrm{~min}$ at $4{ }^{\circ} \mathrm{C}$ was discarded and the supernatant used in some of the experiments.

Agglutination reactions. Whole yeast cells adjusted to $\mathrm{OD}_{660}=0.5$ were used. Slide and tube agglutination tests were carried out with appropriately diluted antibody (whole antiserum titre as determined by tube agglutination $1: 80$ ). Controls consisted of cells treated with globulins of preimmune serum.

Native PAGE. Citrate buffer extracts of yeast cells precipitated with methanol and dissolved in PBS as described for antigen preparation were used. The protein concentration of the samples was determined by the Lowry method and $50 \mu \mathrm{l}$ samples containing $1 \mathrm{mg}$ protein $\mathrm{ml}^{-1}$ were used for electrophoresis. The proteins in the samples were separated in $7.5 \%(\mathrm{w} / \mathrm{v})$ acrylamide gels according to the method of Laemmli (1970). The gels were stained with Coomassie blue R-250 staining solution ( $0 \cdot 2 \%$ Coomassie blue R- $250 ; 40 \%$ methanol; $10 \%$ acetic acid) and destained in $5 \%$ methanol containing $7.5 \%$ acetic acid. Samples dialysed against the tank buffer $(0.025 \mathrm{M}$-Tris base and $0.192 \mathrm{M}$-glycine; $\mathrm{pH} 8.3$ ) were used for electrophoresis.

Indirect ELISA. EDTA-washed yeast cells suspended in absolute ethanol to $\mathrm{OD}_{660}=0.1$ were used. One hundred microlitre volumes of the cell suspension in ethanol were applied to the wells of a polyvinyl microtitre plate. The wells were coated with the cells by fixing due to evaporation of the ethanol at $37^{\circ} \mathrm{C}$.

The coated wells were thoroughly rinsed with PBS containing $0.05 \%$ Tween 20 , and $100 \mu$ l of the antibody (diluted $1: 500$ ) was added to each test well. After incubation for $1 \mathrm{~h}$ at $37^{\circ} \mathrm{C}$, the wells were repeatedly washed with PBS. The wells were then supplied with $100 \mu$ peroxidaseconjugated anti-rabbit IgG (Sigma). After 30 min incubation, the wells were washed with PBS and the presence of bound peroxidase was determined using $0.005 \% \mathrm{H}_{2} \mathrm{O}_{2}$ solution containing 3,3',5,5'-tetramethylbenzidine (Tijssen, 1985). Coated wells treated with preimmune globulins and reacted with peroxidase conjugate as above served as control. The amount of antibody and conjugate added to each well was determined by chessboard titration.

Preparation of monovalent antigen-binding sites of immunoglobulins. Monovalent binding sites of immunoglobulins were made using the enzyme papain (Porter, 1959). Gamma globulins of cross-absorbed antibody preparation were lyophilized and used. Gamma globulins $(150 \mathrm{mg})$ and papain $(1.5 \mathrm{mg})$ were dissolved in $10 \mathrm{ml}$ buffer $(0.1 \mathrm{M}-$

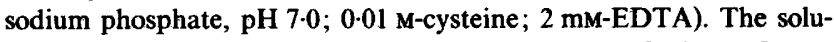
tion was incubated at $37^{\circ} \mathrm{C}$ for $18 \mathrm{~h}$ in the presence of toluene. It was then dialysed against distilled water with vigorous stirring and several changes of the outer liquid over $48 \mathrm{~h}$. This procedure, which removes cysteine and EDTA and facilitates oxidation, inactivates the enzyme (Porter, 1959). The non-diffusible digestion product was treated with protein A (insoluble; Sigma; $200 \mathrm{mg}$ ) to absorb the Fc portions. The supernatant after centrifugation was freeze-dried and used. Presence of the active antigen-binding portion of the antibody in the preparation was tested by agglutination of monovalent-antibody-coated yeast cells in the presence of anti-rabbit goat IgG and by ELISA reactions using immobilized yeast cells coated with monovalent antibody and reacted with peroxidase-conjugated anti-rabbit goat IgG.

\section{Results and Discussion}

\section{Flocculation of S. cerevisiae NCYC 227}

S. cerevisiae NCYC 227 grown in the synthetic medium showed characteristic flocculation from the late exponential phase of growth, remaining mainly as single cells during the early exponential phase (Table 1). Mannose inhibited flocculation (results not presented), as has been shown for some other flocculating yeasts (Miki et al., 1982).

\section{Antigenic variation in the yeast cell wall during the transition from the non-flocculent to the flocculent state}

The results of the Ouchterlony double diffusion test using cells of different growth phases as antigens versus antibodies raised against citrate buffer extracts of late stationary phase cells indicated the appearance of a new antigen during the transition from the non-flocculent to

Table 1. Flocculation of S. cerevisiae NCYC 227 at different growth phases

\begin{tabular}{clc}
\hline \hline $\begin{array}{l}\text { Culture } \\
\text { age (h) }\end{array}$ & Growth phase & $\begin{array}{c}\text { Degree of } \\
\text { flocculation* }\end{array}$ \\
\hline 8 & Mid-exponential & - \\
10 & Mid-exponential & - \\
12 & Late-exponential & + \\
15 & Early stationary & +++ \\
18 & Mid-stationary & +++ \\
24 & Late stationary & +++ \\
\hline \hline
\end{tabular}

* -, No flocculation; ++++ , extremely flocculent. 


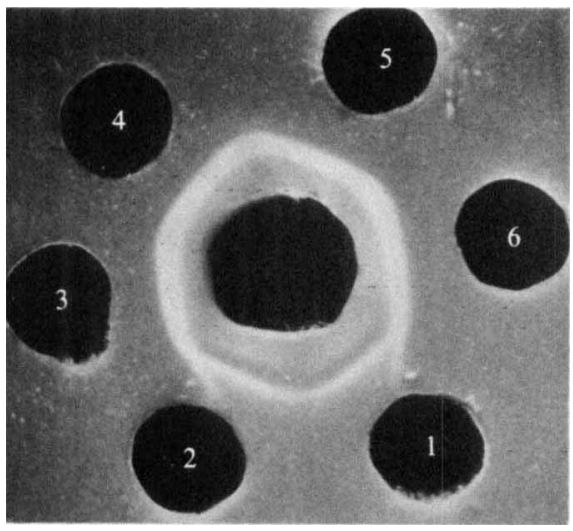

Fig. 1. Immunodiffusion reactions of the antibody raised against citrate buffer extracts of late stationary phase cells of $S$. cerevisiae NCYC 227 ( $400 \mu 1$; centre well). Ammonium-sulphate-precipitated immunoglobulins dissolved in a minimum volume of 0.1 M-PBS after dialysis were used at a dilution of $1: 6$ in $0.1 \mathrm{M}$-PBS. The antigens were whole cells of $S$. cerevisiae NCYC $227\left(200 \mu \mathrm{l} ; \mathrm{OD}_{600}=2 \cdot 0\right)$ harvested at various phases of growth: 1 , early exponential phase $(4 \mathrm{~h}) ; 2$, midexponential phase $(8 h) ; 3$, late exponential phase $(12 h) ; 4$, early stationary phase $(16 \mathrm{~h}) ; 5$, mid-stationary phase $(20 \mathrm{~h}) ; 6$, late stationary phase $(48 \mathrm{~h})$.

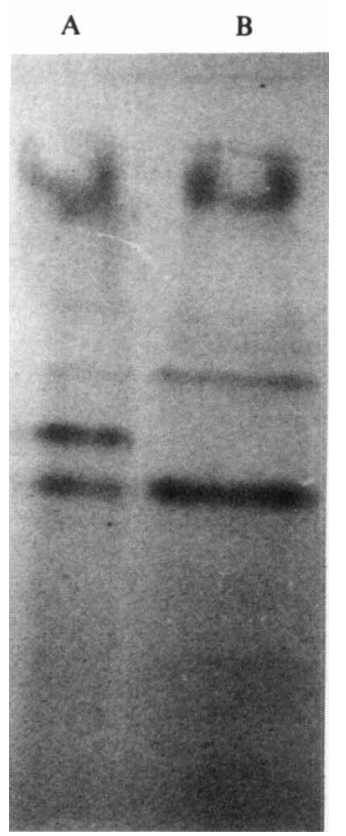

Fig. 2. Native PAGE of citrate buffer extracts of flocculent cells (midstationary phase of growth; A) and non-flocculent cells (early exponential phase of growth; B). Fifty micrograms of protein was loaded in each lane. After electrophoresis in $7.5 \%$ acrylamide gel using Tris/glycine buffer ( $\mathrm{pH} 8 \cdot 3$ ), protein bands were stained with Coomassie blue R-250.

the flocculent state (Fig. 1). Variation also occurred in the protein pattern of the citrate buffer extracts of the two types of cells as determined by PAGE (Fig. 2). Reactions of the cross-absorbed antibody (Fig. 3)

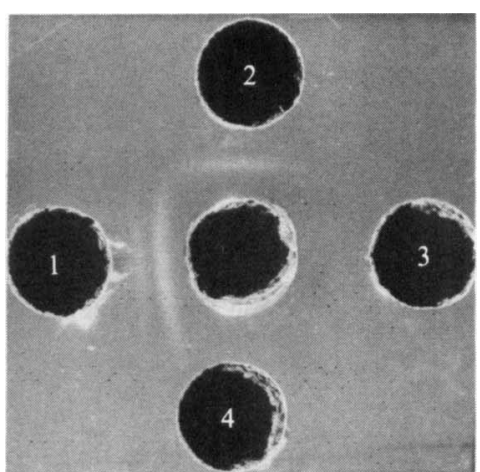

Fig. 3. Immunodiffusion reactions of cells from late stationary phase cultures (centre well; $200 \mu \mathrm{l}, \mathrm{OD}_{660}=2.0$ ) with: 1 , whole antibody $(1: 6$ dilution in $0.1 \mathrm{M}-\mathrm{PBS} ; 100 \mu \mathrm{l}) ; 2$, antibody cross-absorbed with cells from an $8 \mathrm{~h}$ culture $(1: 4$ dilution in $0 \cdot 1 \mathrm{M}$-PBS; $100 \mu \mathrm{l}) ; 3,0 \cdot 1 \mathrm{M}$-PBS pH 7.2 (control); and 4, preimmune globulins (1:1 dilution in $0.1 \mathrm{M}$ PBS; $100 \mu \mathrm{l})$.

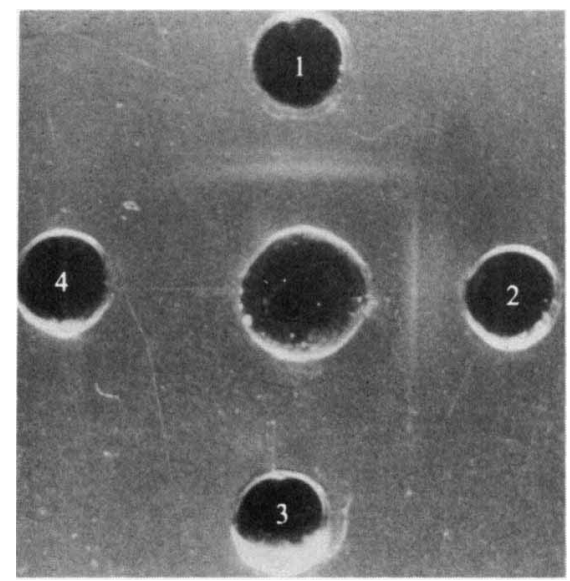

Fig. 4. Immunodiffusion reactions of the antibody (centre well; $200 \mu \mathrm{l}$; $1: 6$ dilution) against: 1 , cells from a late stationary phase culture $\left(100 \mu \mathrm{l} ; \mathrm{OD}_{660}=2 \cdot 0\right), 2$, citrate buffer extracts of cells from a late stationary phase culture precipitated with methanol and dissolved in $0.05 \mathrm{M}$-PBS $\left(100 \mu \mathrm{l}\right.$; protein concentration $\left.1 \mathrm{mg} \mathrm{m}^{-1}\right) ; 3$, supernatant of concanavalin-A-precipitated citrate buffer extracts of cells from a late stationary phase culture $(100 \mu \mathrm{l})$ [methanol-precipitated citrate buffer extract dissolved in $0 \cdot 1 \mathrm{M}$-PBS containing $1 \mathrm{mg}$ protein $\mathrm{ml}^{-1}$ was treated with concanavalin $\mathrm{A}\left(1 \mathrm{mg} \mathrm{m}^{-1}\right)$; the precipitate obtained was removed by centrifugation at $3600 \mathrm{~g}$ for $15 \mathrm{~min}$ at room temperature]; 4 , pronase-treated cells from a late stationary phase culture $(100 \mu \mathrm{l})$ [whole cells in $1 \mathrm{M}$-sodium phosphate buffer, $\mathrm{pH} 7.5\left(\mathrm{OD}_{660}=2.0\right)$ were treated with $1 \mathrm{mg}$ pronase $\mathrm{E} \mathrm{ml}^{-1}$ (Sigma) for $15 \mathrm{~min}$ at $37^{\circ} \mathrm{C}$; cells washed repeatedly and suspended in $0.05 \mathrm{M}$-PBS were used].

confirmed the above results. Agglutination of cells from late stationary phase cultures in the presence of crossabsorbed antibody preparation suggested surface localization of these antigens on the cell wall. A number of reports have established mannoprotein as the surface layer of S. cerevisiae (Phaff, 1971; Rosenfeld \& Ballou, 1972), and negative reactions of concanavalin-A-precipitated antigen extracts (Fig. 4) and stability of the 


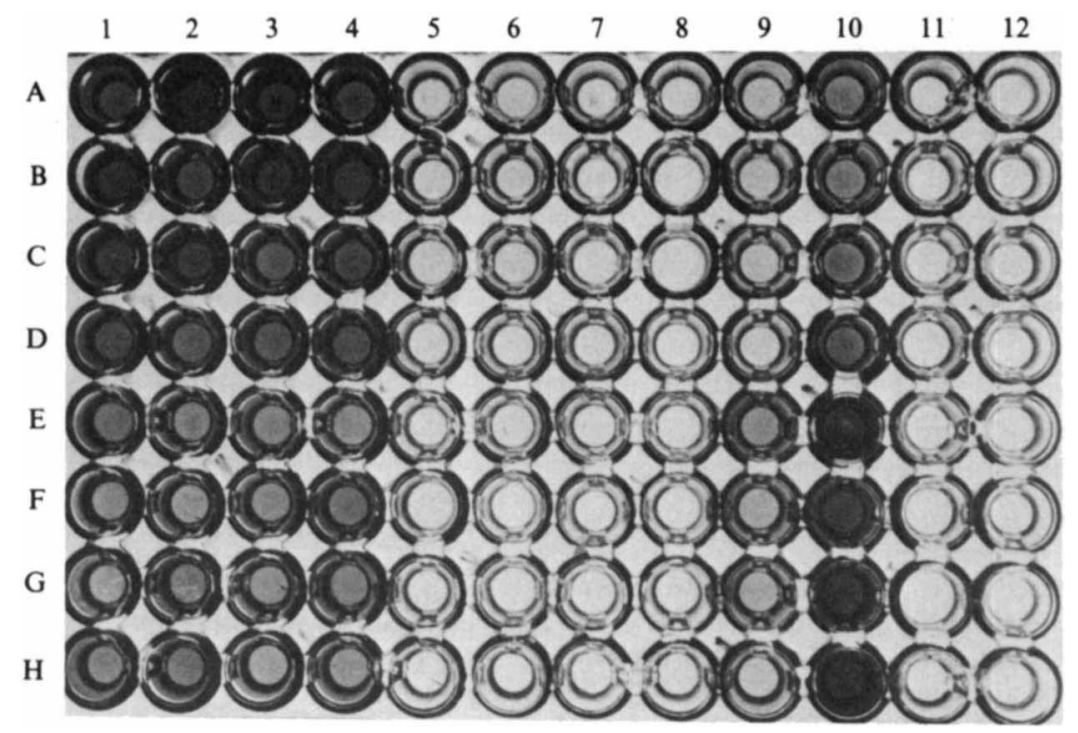

Fig. 5. ELISA reactions. Polyvinyl microtitre plates coated with cells of $S$. cerevisiae were reacted with $100 \mu$ l of whole antibody or cross-absorbed antibody $(1: 500$ dilution in $0 \cdot 1 \mathrm{M}$-PBS). After washing, $100 \mu \mathrm{l}$ peroxidase-conjugated anti-rabbit goat IgG was added. Bound peroxidase activity in the washed wells was determined by using $\mathrm{H}_{2} \mathrm{O}_{2}$ solution containing tetramethylbenzidine. Wells 1 to 4: series A to D, reactions of cross-absorbed antibody with cells of strain NCYC 227 from a late stationary phase culture; series E to $H$, reactions of cross-absorbed antibody with cells of strain NCYC 227 from a late exponential phase culture. Wells 5 to 8 : series A to D, reactions of cross-absorbed antibody with cells of strain NCYC 227 from a mid-exponential phase culture; series E and F, reactions of cross-absorbed antibody with cells of strain NCYC 227 from an early exponential phase culture; series G and H, reactions of crossabsorbed antibody with cells of NCYC 431 (wells 5 and 6) and NCYC 619 (wells 7 and 8). Wells 9 and 10 : series A to H, reactions of the unabsorbed antibody with cells of S. cerevisiae NCYC 431 (well 9; A and B), CS 101 (well 9; C and D), NCYC 619 (wells 9; E and F), NCYC 620 (well 9; G and H), early exponential phase cells of NCYC 227 (well 10; A to D), and late exponential phase cells of NCYC 227 (well $10 ; \mathrm{E}$ to $\mathrm{H}$ ). Wells 11 and 12 : series $\mathrm{A}$ to $\mathrm{G}$, control reactions of unabsorbed antibody (A to D) and absorbed antibody (E to $H$ ) in uncoated wells.

antigens despite extraction after autoclaving with buffer indicate the glycoprotein nature of the antigens of strain NCYC 227. The results of pronase digestion of the antigens (Fig. 4) suggest involvement of protein groups of the glycoprotein in reactions with the antibody.

Non-flocculating and flocculating strains of $S$. cerevisiae could not be distinguished by ELISA using whole antibody preparation (Fig. 5). However, using crossabsorbed antibody for the ELISA, cells of $S$. cerevisiae NCYC 227 at the flocculating stage could be clearly distinguished from other strains of $S$. cerevisiae and from non-flocculating cells of S. cerevisiae NCYC 227 (Fig. 5). These results further confirm the formation of the identified glycoprotein only when the cells have entered the flocculent state. This finding could explain the results of Campbell et al. (1968) and Campbell \& Brudzynski (1966), who found no antigenic differences between flocculent and non-flocculent strains of $S$. cerevisiae. They used aerobically grown cells from 3-d-old agar slants for their studies.
Involvement of a cell wall surface antigen in the flocculation of S. cerevisiae NCYC 227

The above results suggested synthesis of a specific antigen (a glycoprotein) on the cell wall surface during the mid-exponential phase of growth, when the cells characteristically flocculated. Increase in the concentration of this antigen concurrently with increased flocculation of cells (Fig. 5) suggested its involvement in flocculation. Results obtained using monovalent antibody confirmed the involvement of this glycoprotein antigen in flocculation. Flocculent cells dispersed with EDTA and coated with monovalent antibody specific for this antigen did not reflocculate, while removal of the coated antibody with $1 \mathrm{M}$-Tris/ $\mathrm{HCl}(\mathrm{pH} 10 \cdot 2)$ caused reflocculation of the cells in the presence of $50 \mathrm{mM}$ $\mathrm{CaCl}_{2}$. The effect described was confirmed to be due to the presence of monovalent antibody by the agglutination of such coated cells in the presence of anti-rabbit goat IgG (results not shown). The surface localization of 
the antigen necessitated the use of monovalent antibody fragments, since divalent antibodies induced agglutination, which could not be differentiated from flocculation.

Based on the preliminary observations of Marfey $e t$ al. (1977), Beavan et al. (1979) suggested floc-forming ability in yeasts to be due to the appearance of a nonenzymic, acidic protein in the surface layers of the cell wall. Our studies described above indicate the appearance of an antigen (a glycoprotein) during the transition of the yeast cells from the non-flocculent to the flocculent state, causing flocculation to occur. Mannose inhibition of flocculation suggests this glycoprotein to have a lectinlike function as suggested by Miki et al. (1982). The thermostability of this glycoprotein and its localization on the cell wall surface substantiate earlier observations on flocculation of heat-killed cells (Mill, 1964) and isolated cell walls of flocculent yeasts (see Calleja, 1987).

The authors are grateful to the Director, Central Food Technological Research Institute Mysore, for facilities, and to the Area-Coordinator of the discipline for his keen interest and encouragement.

\section{References}

Amri, M. A., Bonaly, R., Duteurtre, B. \& Moll, M. (1982). Yeast flocculation: influence of nutritional factors on cell wall composition. Journal of General Microbiology 128, 2001-2009.

Beavan, M. J., Belki, D., Stewart, G. G. \& Rose, A. H. (1979) Changes in electrophoretic mobility and lytic enzyme activity associated with developments of flocculating ability in Saccharomyces cerevisiae. Canadian Journal of Microbiology 25, 888-895.

Calleja, G. B. (1987). Cell aggregation. In The Yeasts, vol. 2, pp. 165237. Edited by A. H. Rose. London: Academic Press.

CAMPBELL, I. \& BRUDZYNSKI, A. (1966). Serological studies on brewing yeasts. Journal of the Institute of Brewing 72, 556-560.

CAmpbell, I., Robson, F. O. \& Hough, J. S. (1968). Serological investigations of fining and flocculent yeasts. Journal of the Institute of Brewing 74, 360-364.

Cawley, T. N. \& Ballou, C. E. (1972). Identification of two Saccharomyces cerevisiae cell wall mannan chemotypes. Journal of Bacteriology 111, 690-695.

Harris, J. O. (1959). Possible mechanism of yeast flocculation. Journal of the Institute of Brewing 65, 5-6.
JAYATISSA, P. M. \& Rose, A. H. (1976). Role of phosphomannan in flocculation of Saccharomyces cerevisiae. Journal of General Microbiology 96, 165-174.

LAEMMLI, U. K. (1970). Cleavage of structural proteins during the assembly of the head of bacteriophage T4. Nature, London 227, 680685.

LyoNs, T. P. \& Hough, J. S. (1970). Flocculation of brewer's yeast. Journal of the Institute of Brewing 76, 564-571.

Lyons, T. P. \& Hough, J. S. (1971). Further evidence for the cross bridging hypothesis for flocculation of brewer's yeast. Journal of the Institute of Brewing 77, 300-305.

MARFEY, P., SORENSEN, S. B. \& OTTENSEN, M. (1977). Studies on yeast flocculation. Comparison of enzymatic digests of flocculent and non flocculent cells of Saccharomyces carlsbergensis. Carlsberg Research Communications 42, 353-367.

Miki, B. L. A., Poon, N. H., James, A. P. \& Seligy, V. L. (1981). Flocculation in Saccharomyces cerevisiae: mechanism of cell-cell interactions. In Current Developments in Yeast Research, pp. 193-198. Edited by G. G. Stewart \& I. Russell. Toronto: Pergamon Press.

Miki, B. L. A., Poon, N. H., James, A. P. \& Seligy, V. L. (1982) Possible mechanism for flocculation interactions governed by gene FLOI in Saccharomyces cerevisiae. Journal of Bacteriology 150, 878889.

MiLL, P. J. (1964). The nature of interactions between flocculent cells in the flocculation of Saccharomyces cerevisiae. Journal of General Microbiology 35, 61-68.

PHAFF, H. J. (1971). Structure and biosynthesis of the yeast cell envelope. In The Yeasts, vol. 2, pp. 135-210. Edited by A. H. Rose \& J. S. Harrison. New York \& London: Academic Press.

PORTER, R. R. (1959). The hydrolysis of rabbit $\gamma$-globulin and antibodies with crystalline papain. Biochemical Journal 73, 119-126.

Rose, A. H. (1984). Physiology of cell aggregation: flocculation by Saccharomyces cerevisiae as a model system. In Microbial Adhesion and Aggregation, pp. 323-335. Edited by K. C. Marshall. Berlin: Springer-Verlag.

Rosenfeld, L. \& Ballou, C. E. (1972). Genetic control of yeast mannan structure (biological basis for the transformation of $S$ cerevisiae somatic antigen). Journal of Biological Chemistry 249, 23192321 .

StEWART, G. G. (1975). Yeast flocculation. Brewers Digest 50, 42-57.

STEWART, G. G. \& Goring, T. E. (1976). Effect of some monovalent and divalent metal ions on the flocculation of brewer's yeast strains. Journal of the Institute of Brewing 82, 341-342.

Stewart, G. G., Russell, I. \& Garrison, I. F. (1975). Some considerations of the flocculation characteristics of ale and lager yeast strains. Journal of the Institute of Brewing 81, 248-257.

TAYLOR, N. W. \& ORTON, W. L. (1978). Aromatic components and sugars in flocculation of Saccharomyces cerevisiae. Journal of the Institute of Brewing 84, 113-114.

TIJSSEN, P. (1985). Practice and theory of immunoassays. In Laboratory Techniques in Biochemistry and Molecular Biology, vol. 15, p. 549. Amsterdam, New York \& Oxford: Elsevier. 